\title{
US Policy on Dollarization of the World Economy
}

\author{
Chuvakhina L., Nasirbeik A. , Ivanovskaya Zh. \\ Department of World Economy and International Business, Financial University under the Government of the Russian Federation, 49, \\ Leningradsky avenue, Moscow, 125993, Russia
}

Received March 8, 2021; Revised August 18, 2021; Accepted August 26, 2021

\section{Cite This Paper in the following Citation Styles}

(a): [1] Chuvakhina L., Nasirbeik A., Ivanovskaya Zh. , "US Policy on Dollarization of the World Economy," Universal Journal of Accounting and Finance, Vol. 9, No. 4, pp. 885 - 893, 2021. DOI: 10.13189/ujaf.2021.090434.

(b): Chuvakhina L., Nasirbeik A., Ivanovskaya Zh. (2021). US Policy on Dollarization of the World Economy. Universal Journal of Accounting and Finance, 9(4), 885 - 893. DOI: 10.13189/ujaf.2021.090434.

Copyright $\bigcirc 2021$ by authors, all rights reserved. Authors agree that this article remains permanently open access under the terms of the Creative Commons Attribution License 4.0 International License

\begin{abstract}
In its essence and content, dollarization is one of the keys and most significant phenomena of modern dynamically developing international monetary and financial relations. There are different theoretical approaches to determining the economic essence and content of the complex and contradictory phenomenon of dollarization. Different scientists have investigated the monetary nature of this phenomenon and have given a comparison of the concepts of official and partial dollarization, based on the degree of economic coverage of dollarization. In this research the process of official dollarization is considered on the example of Eurasian Economic Union (EAEU) member states. The paper examines the scale of financial dollarization in the EAEU member states, where, due to the loss of residents' confidence in the monetary policy and the national monetary unit, the functions of the national currency are partially replaced by the US dollar. Furthermore, the role of the US Federal Reserve in the implementation of dollarization of the foreign economies is analyzed. The article substantiates the intention of the US Federal Reserve to take steps to dollarize the foreign countries' economy in the context of the started process of de-dollarization of the world economy. The most active supporters of de-dollarization are Russia, China, and Iran. Their efforts are aimed at weakening the dominant position of the dollar as a key reserve currency, the currency of international settlements. In the current condition of the world economic development, it is unlikely to expect a weakening of the position of the US dollar, given the role of the US dollar in the trade of oil and petroleum products. The petrodollar system is the basis of the US dominance in the global financial system and the key to the stability of
\end{abstract}

the US dollar. As a result, countries are forced to buy dollars in order to be able to purchase oil on the open market. While the demand for the US dollar will remain at a high level, it is not necessary to talk about the success of de-dollarization and the transition from an American-centered monetary and financial system to a polycentric one in the near future.

Keywords Dollarization, Federal Reserve, EAEU, De-dollarization

\section{Introduction}

In the context of increasing financial globalization, the processes of dollarization of the world economy have been intensified. Dollarization as a phenomenon of modern economic reality is based on the growing interest of states in attracting the US dollar as an official monetary unit against the background of a loss of confidence in the national currency.

The dominance of the US dollar puts states in the position of being dependent on the actions of the American financial regulator. Dollarization distorts the national economy of the state, increases the dependence of the financial system on the monetary policy of the US Federal Reserve. The accumulation of dollar reserves contributes to interest-free and perpetual lending to the United States.

Studies of the problems of dollarization became most relevant after the processes of dollarization affected the countries of the post-Soviet space, whose currencies, in the 
conditions of monetary destabilization, delegated part of their functions to the US dollar for carrying out monetary operations. The level of financial dollarization in the Eurasian Economic Union (EAEU) member states is significantly higher in comparison with other European states, which is explained by higher inflation, macroeconomic volatility, strict control over the exchange rate, and the growth of foreign currency deposits.

The processes taking place in the world economic system prove that the level of dollarization of the world economy remains very high, which contributes to the strengthening of the US dollar, despite the intentions of a number of countries to weaken the position of the US currency and neutralize the efforts of the US Federal Reserve to create a global dollar zone.

Russia has taken the toughest position on the issue of de-dollarization of the national economy in recent years, going to reduce the share of the US dollar in the country's international reserves. Iran is an opponent of the US dollar after the adoption of the Public Law 115-44 (CAATSA) on Economic Sanctions in the United States in August 2017. Attempts to weaken the US dollar, although in a rather veiled form, are being made by China, which is increasingly advocating the yuanization of the world economy.

Different attempts of some oil exporting countries to get away from US Dollar in the settlements for oil ended unsuccessfully. The main "defender" of the policy of financial dollarization and the search for the weakest links for increasing the expansion of the dollar, using methods of monetary influence, is the US Federal Reserve, as a global financial regulator. In the conditions of the current crisis caused by COVID-19, we can expect that the question of dollarization of national economies will gain much more attention, given the financial problems that many countries will face in the near future. Therefore, the aim of this study is to analyze the current position of dollar in the selected countries like Armenia, Belarus, Kazakhstan, Kyrgyzstan, and Russia.

\section{Theoretical Aspects of the Study}

There are two approaches to the study of the concept of dollarization. Supporters of the monetary concept Ozsoz E. [1], Salama P. [2], Savastano M. A. [3] consider "dollarization" as a phenomenon of the money market, which is based on the possibility of replacing the functions of the national currency with a foreign one. Speaking about "dollarization", Ozsoz E. and Salama P. mean the replacement of the national currency with the US dollar, which is in the greatest demand among other world currencies. The same position is held by Garcia-Escribano M., Sosa S. [4], who define dollarization as a process in which a significant share of the assets and liabilities of residents are denominated in

\section{US dollars.}

Proponents of the monetary concept consider only monetary assets when calculating dollarization indicators. According to the financial concept, which is supported by Goujon M. [5], Basso H., Calvo-Gonzalez O., Jurgilas M. [6], Honohan P. [7], dollarization is not only the replacement of monetary assets, but a wider set of non-monetary financial assets, for example, the replacement of bonds, bills and other securities denominated in national currency with foreign currency analogues.

There is still no unambiguous assessment of the advantages and disadvantages of dollarization in the economic literature. Theoretical discussions around the problem of dollarization are actualized during the period of increasing crisis phenomena. Dollarization, according to L. G. Chuvakhina [8], destroys the internal financial system of economically unstable states, leads to a crisis of solvency, distorts the national economy, which begins to work not for the state's own needs, but based on the interests of the United States. According to Arteta C. O. [9], financial dollarization increases the possibility of a crisis, in which the risks of dollarization are particularly acute. Thus, with low dollar liquidity and at the same time a high share of foreign currency deposits, banks are not always able to cope with the mass withdrawal of dollar deposits by depositors in conditions when the role of the central bank as a lender of last resort is limited. Excess of liquid bank liabilities over their dollar assets may lead to default. At the same time, Arteta C. O. does not deny the advantages of dollarization in conditions of macroeconomic instability since dollar loans and deposits increase the financial stability of national economies and help avoid demonetization. According to researchers Gavranić K. and Miletić D. [10], the US dollar remains the main currency in international reserves today, given the position that the global financial system provides it. The current volume of the dollar almost reaches $2 / 3$ of the total amount of international foreign exchange reserves, which entails risks associated with fluctuations in the dollar exchange rate.

Economic researchers are particularly interested in the dollarization of the economies of the post-Soviet countries. Attempts to estimate the volume of US dollars in circulation in the economies of these countries were made by Feige E. L., Dean J. W. [11], Tumarova T. G. and Kornilovich S.G. [12] based on data from analytical and statistical reports on the movement of dollar cash flows.

According to Levy-Yeyati E. [13], dollarization cannot be considered as an inevitable phenomenon, since there are countries that advocate de-dollarization of the national economy. As the main stages of de-dollarization, Levy-Yeyati E. highlights measures to eliminate the binding of prices to foreign currency, the transition to the implementation of settlements in the national currency. According to Levy-Yeyati E., in order to abandon 
dollarization, it is necessary to adopt financial de-dollarization as a state policy.

It is possible to weaken the dollar hegemony from the point of view of Platonova I. [14], particularly by switching countries to payments in other currencies for goods supplied. An example is the transition of the EU and China countries from the traditional dollar, respectively, to settlements in euros and yuan for Iranian oil supplied, to settlements in euros for energy imports from Norway. Meanwhile, we should not forget that today the euro and the yuan cannot compete with the US dollar. The strengthened position of the US dollar against the euro is confirmed in its research by Dabrowski M. [15] If with the introduction of the euro there was a point of view that the single European currency would become a real competitor to the US dollar, then by the end of 2010 it became clear that the euro occupied the niche of its predecessors - the German mark and the French franc. Today's international position of the euro is a stable regional currency, which is inferior to the leadership of the US dollar.

In general, the desire of countries to push the US dollar from international settlements, according to researchers Faudot A. and Ponsot J. [16] it did not lead to a radical change in the share of currencies in the global foreign exchange market.

According to the scientist Siddiqui K. [17], despite COVID19 and the adverse consequences for the US economy, the dollar will still remain the leading currency in international settlements. The researcher concludes that it will take at least 20-30 years for there to be a real possibility of displacing the US dollar from its positions.

\section{Research}

If the US dollar is declared the official monetary unit, the national currency is replaced by the dollar. The acquisition of the status of an official currency by the US dollar with the approval of government structures means the state's refusal to issue a national monetary unit, which leads to the loss of monetary sovereignty and falling into monetary dependence on the United States. The role of the national Bank, in fact, is reduced to zero. The issue of the dollar is carried out by the US Federal Reserve. Countries that have de jure switched to the US dollar are forced to pay seigniorage to the US Federal Reserve - the issuer of the US dollar. Hence, the interest of the Federal Reserve in the development and expansion of the scale of dollarization is clear. The difference between the nominal value of the currency and the cost of its manufacture goes to the US budget. The demand for the US dollar generated by dollarization supports the overall monetary demand in the US economy.

The introduction of the US dollar into circulation occurs simultaneously with the withdrawal of the local currency from circulation. When switching to the US dollar from the national currency, the exchange rate at which the conversion is carried out is set.

By declaring the US dollar, the official currency, the state recognizes the impossibility of conducting an independent credit policy from the Federal Reserve, acting as the ultimate credit authority for local commercial banks. In the event of a shortage of dollar liquidity, a state with an officially dollarized economy will not be able to contain the bankruptcy of commercial banks. Hence, the dissatisfaction of the governments of dollarized countries with the increase in the Federal Reserve's interest rate is understandable.

Dollarization of the economies of foreign countries allows the United States to increase commodity exports to these countries, which is extremely important for the United States, where the trade balance is reduced to a deficit. Dollarized countries act as sales markets for American products.

With the loss of confidence in the national monetary unit on the part of the population and economic entities, the functions of the national currency are partially replaced by the US dollar. The transition to partial dollarization can be explained by the intention of residents to protect their assets from the risk of depreciation of the national currency. The basis for the transition to partial dollarization is the removal or easing of restrictions on the implementation of operations for the exchange of national currency into a foreign currency, for making payments, conducting non-cash settlements, opening of bank deposits in foreign currency, both on the territory of the country and in banks abroad. The opening of foreign currency deposits in foreign banks, can be considered as the dollarization of savings, which is directly related to the outflow of capital from the country.

The experience of functioning of fully dollarized economies is limited. Currently, the US dollar has been used as an official monetary unit in Panama since 1904, Ecuador since 2000, and El Salvador since 2001.

In the late 1990s, the United States prepared a list of countries that could switch to using the US dollar as an official monetary unit. Latin American countries were considered as the main contenders, considering the deterioration of their economic situation, the increase in external debt, and the growth of distrust of national currencies. The US Federal Reserve showed special interest in Argentina, Venezuela, and Brazil. In 1999, Argentina announced the possible rejection of the national currency (peso) in favor of the US dollar after negotiations with representatives of the Ministry of Finance and the US Federal Reserve. However, the project of official dollarization of the country, developed with the active participation of the US Federal Reserve, was not implemented, as well as in Brazil and Venezuela [18].

In the 1990s, the processes of partial dollarization affected the countries of the post-Soviet space, whose 
currencies, in the conditions of monetary destabilization, transferred part of their functions to the US dollar. It concerns the monetary transactions and savings. The real scale of dollarization of the economies of the states of the Eurasian region is limited to the financial sector since there is a ban on carrying out settlements in foreign currency on their territory. In the context of a sharp depreciation of national currencies in 2014-2016, and, accordingly, the growth of foreign currency deposits in the EAEU countries intensified the processes of financial dollarization. Residents of the countries own significant financial assets in foreign currency. The shares of deposits and loans in national currencies and US dollars from the total amount of all deposits and loans shown in the graphs below allow us to assess the degree of substitution of the functions of the national currency with the US dollar.

Credit \& deposits in national and foreign currencies in Belarus in \%

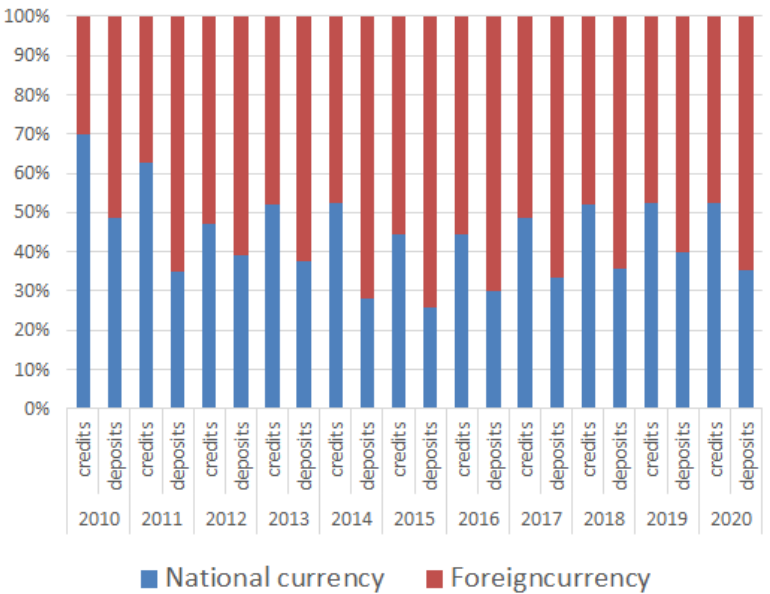

Figure 1. The scale of dollarization in Belarus [19]

Credit \& deposits in national and foreign currencies in Armenia in \%

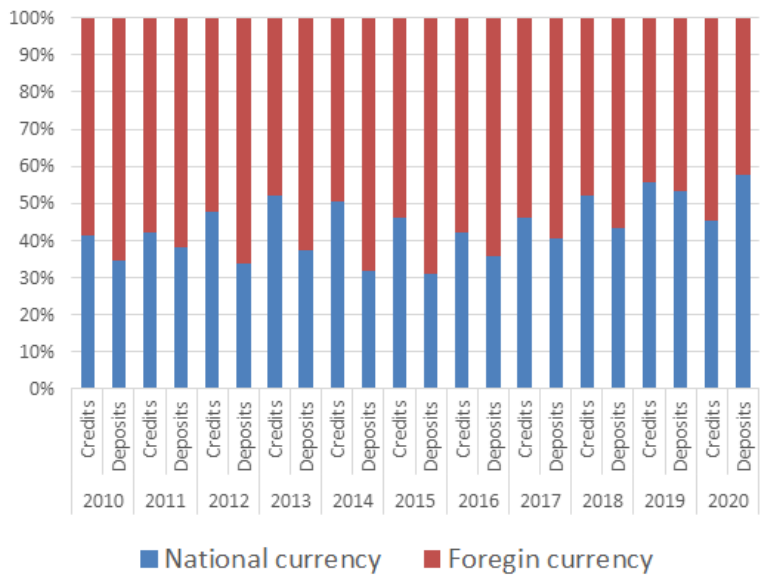

Figure 2. The scale of dollarization in Armenia [20]
Figure 1, illustrating the data for Belarus, shows to what extent the national currency is replaced by the US dollar. The excess of the share of deposits and loans in US dollars over the indicator in the national currency can be explained by inefficient monetary policy, depreciation of the national currency, high inflation, forced denomination of the Belarusian ruble, carried out on July 1, 2016. A high degree of dollarization of the non-cash money supply remains in Belarus.

A high degree of financial dollarization is also characteristic of Armenia (Figure 2), however, unlike other EAEU states, with low inflation in the country. One of the main reasons for the high level of dollarization of Armenia is the money transfers of workers from abroad, mainly from Russia. To hedge currency risks, the received income is converted into US dollars and placed on accounts with national banks or on foreign bank accounts.

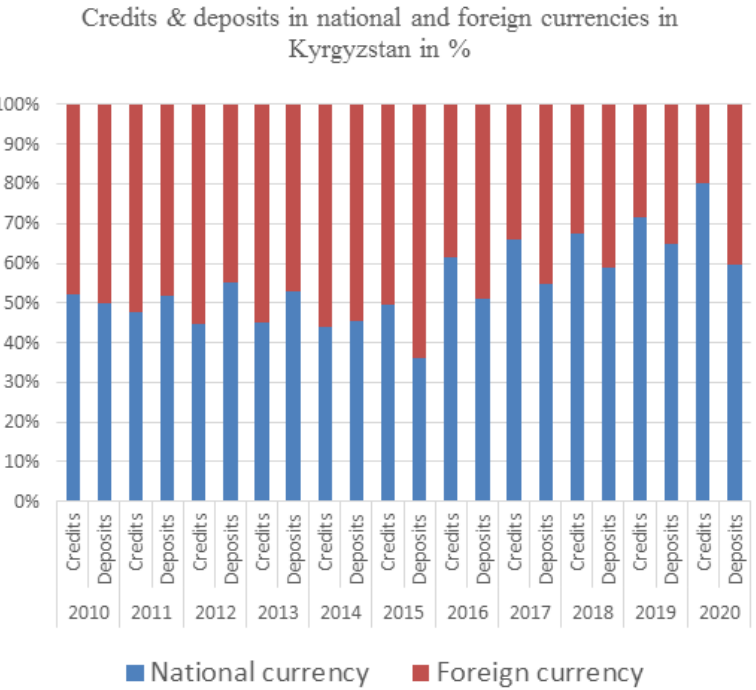

Figure 3. The scale of dollarization in Kyrgyzstan [21]

Credits \& deposits in national and foreign currencies in Kazakhstan in \%

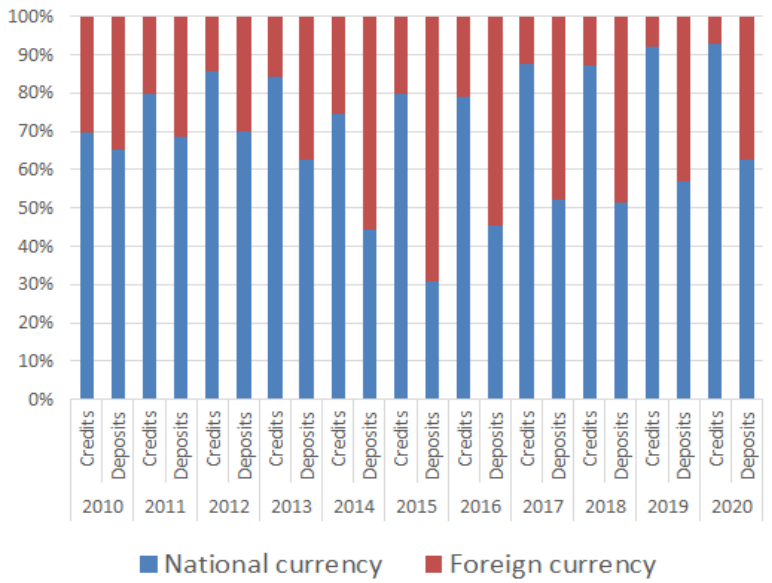

Figure 4. The scale of dollarization in Kazakhstan [22] 
A high degree of dollarization with relatively low inflation is also characteristic of Kyrgyzstan (Figure 3), although, as can be seen from Figure 3, in 2018-2020, the scale of dollarization for deposits and especially for loans has significantly decreased. One of the main reasons for maintaining a relatively high degree of dollarization of deposits, as well as for Armenia, is money transfers of employees working in Russia.

The scale of financial dollarization in Kazakhstan (Figure 4) is higher than in Russia (Figure 5), but lower than in other EAEU countries. Thus, the degree of dollarization of deposits in Belarus exceeded $60 \%$ in 2020 . At the same time, it is too early to talk about a significant, massive drop in deposits in US dollars in Kazakhstan. The slow refusal of residents from the US dollar in favor of the national currency is due to the reluctance of the population to change the traditional habit of "worshipping" the US dollar. A factor of the growth of deposits in the national currency is the increase in the interest rates on deposits by the Central Bank of the country. In this case, deposits in the national currency offer a higher yield than dollar deposits, which to a certain extent contributes to an increase in deposits in the local currency. However, with the growing uncertainty in the economy and the appearance of inflationary risks, the population immediately begins to buy dollars. Confidence in the US dollar especially increases with the growth of its exchange rate.

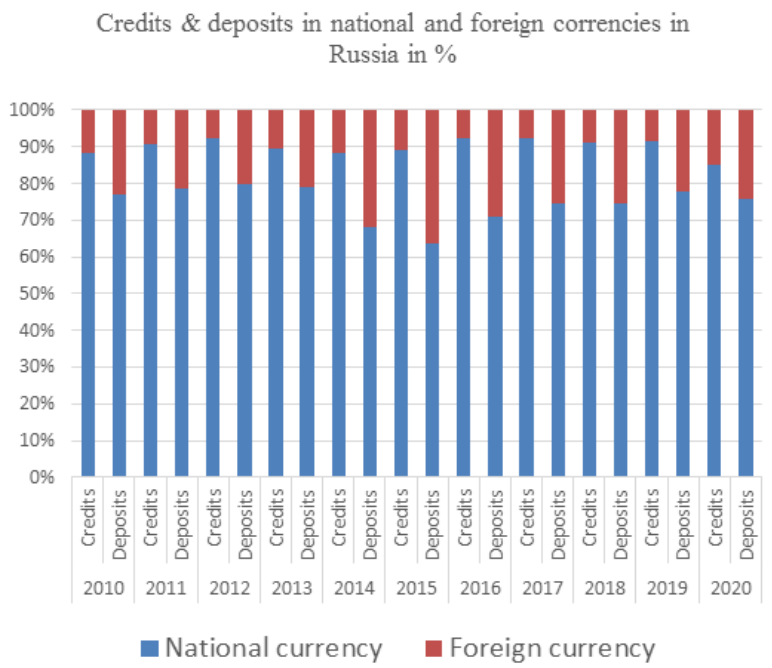

Figure 5. The scale of dollarization in Russia [23]

A significant part of US dollars is in non-cash form on the accounts of Russian banks. In 2014-2015, after the introduction of sanctions against Russia, residents' deposits in US dollars increased significantly. And although, since 2016, there has been a reduction in them, it is not yet necessary to talk about the growth of full confidence in the Russian ruble. The progress in displacing the US dollar over the years under review is very modest. The crisis of 2020 led to an increase in the share of loans and deposits in foreign currency, as can be seen in Figure 5. By reducing the use of the US dollar in the domestic economy, Russia is trying to protect itself from US sanctions, as well as to reduce the influence of the US Federal Reserve's monetary policy instruments.

In 2016-2020, the EAEU countries took measures to de-dollarize the financial system in order to restore the monopoly rights of national currencies in the domestic economy and weaken dollarization. Firstly, it concerns targeting inflation and increasing the flexibility of the exchange rate. This is especially evident in the example of Kazakhstan and Kyrgyzstan. The EAEU countries have introduced a ban on setting prices and tariffs in foreign currency, a ban on lending to the population in US dollars. More substantial guarantees were provided for the insurance of deposits in the national currency.

However, we can speak about real de-dollarization only within the framework of the EAEU, since Russia, placed under strict sanctions, will be forced to reduce its dependence on external factors for the development of the domestic economy, while at the same time leading its partners in the EAEU in this direction. In order to de-dollarize the economy in the Eurasian space, Russia is increasingly promoting the Russian ruble as a means of settlements and payments for the mutual trade of the EAEU states, fully realizing that it is possible to reduce the degree of dollarization of deposits only by increasing settlements between the EAEU countries in local currencies. Meanwhile, settlements in rubles entail additional high risks for business, given the volatility of the Russian ruble and its periodic falls. Although the EAEU countries have somewhat reduced the use of the dollar in the domestic economy, these states still use the US dollar. At the same time, the scale of dollarization differs by country, as can be seen in Figure 6 .

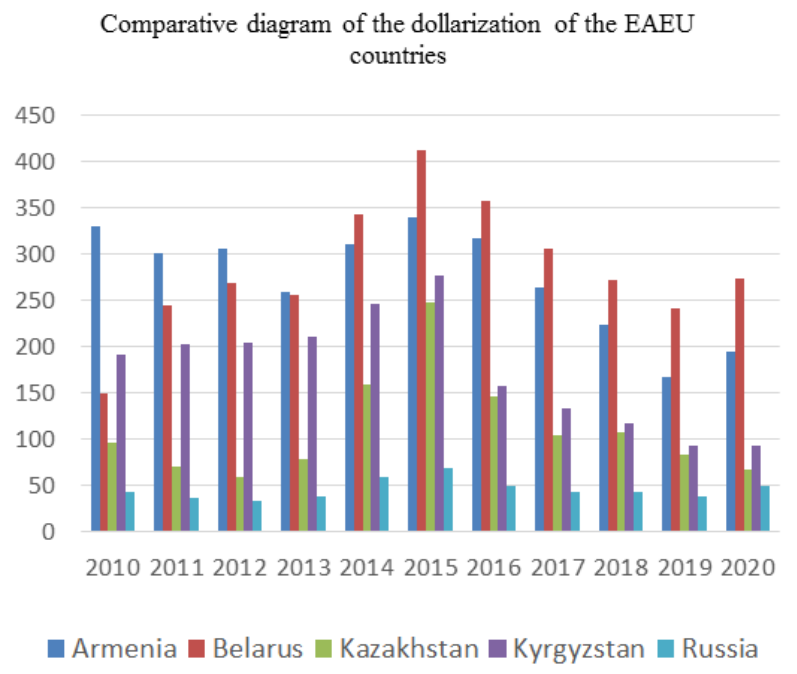

Figure 6. Comparative diagram of the dollarization of the EAEU countries [24]

If before 2014 the highest degree of financial 
dollarization was characteristic of Armenia, then since 2014 Belarus has taken over the "leadership". For all the years under review, Russia maintained the lowest indicator of financial dollarization.

The policy aimed at weakening the dollar's position runs into opposition from the US Federal Reserve, which opposes the weakening of the dependence of the world economy on the US dollar.

Regarding the role of other countries that have taken measures toward de-dollarization we can refer to example of some oil exporting countries trying to refuse US dollar in their oil settlements.

The attempts of Libya and Iraq to get away from the US dollar in the settlements for oil ended unsuccessfully. The refusal of Venezuela in September 2017 to supply oil for US dollars and the transition to settlements in euros, while simultaneously making a decision to convert the country's dollar funds in banks into euros, led to a smooth "withdrawal" of the United States from Venezuelan oil. In March 2019, the United States blocked all potential oil and petroleum products transactions with Venezuela.

Perhaps only Iran managed to restrain the aggressive policy of the United States. In response to the Public Law 115-44 (CAATSA) on economic sanctions against Russia, Iran and the DPRK adopted in the United States in August 2017, the Iranian leadership in February 2018 refused to conduct settlements in US dollars in favor of the euro, the Chinese yuan, and the Iranian rial. The transition to the euro in payments for Iranian oil is explained by the interest of France, Germany and the UK in purchasing Iranian oil. In contrast to the US policy, these countries created in 2019 a special mechanism - the Instrument in Support of Trade Exchanges (INSTEX) - for facilitating commercial settlements between European partners and Iran. INSTEX was then joined by Belgium, Denmark, the Netherlands, Sweden, Norway, and Finland. It was decided to nominate contracts for the supply of Iranian products in euros. Since 2019 India and Iran have completely switched to payments in rupees for oil imports from Iran. According to the agreement reached between the countries, Iran will purchase Indian goods for the rupees received from oil exports. The Government of India has partially exempted Indian importing companies from paying taxes when buying oil from the Iranian state oil company National Iranian Oil Co (NIOC). The main currency of settlements between Russia and Iran is the Russian ruble. At the end of March 2021, China and Iran signed an agreement on strategic and trade partnership for a period of 25 years. Payments for the supply of products of the country are carried out mainly in Chinese yuan.

China supports the weakening of the US dollar, using its capabilities as a leading global trading player. The share of the main crude oil importers is shown in the Figure 7. As the largest consumer of oil and petroleum products, China launched a project to trade oil futures in yuan on the Shanghai Stock Exchange in March 2018.

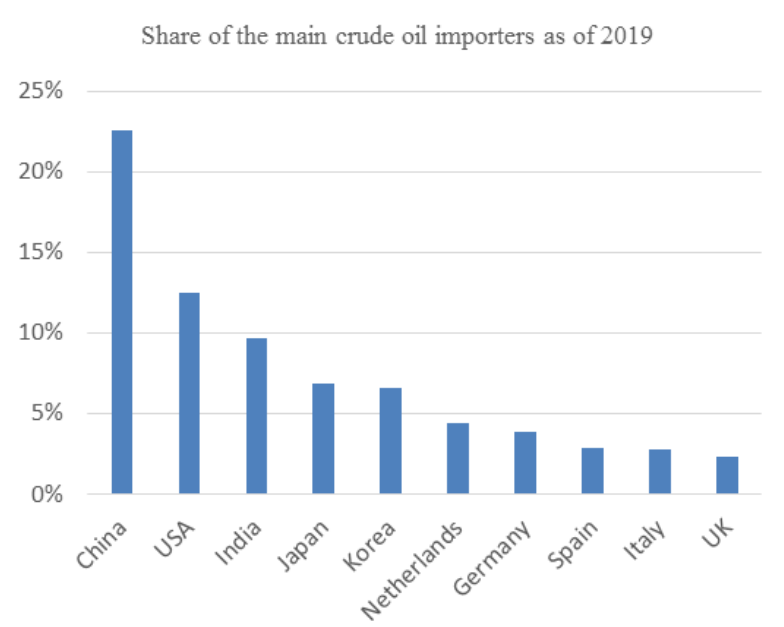

Figure 7. The countries with highest share of crude oil importing [25]

In recent years, China has been trying to force Saudi Arabia, as the world's main oil player, to make a gradual transition to trading in yuan in order to abandon the US dollar, in which physical oil is traditionally traded. China is already paying for oil supplies in yuan with Venezuela, Russia, Iran, and Nigeria. And yet, such a transition will not be fast, since almost all trading contracts are fixed in US dollars. The dollar remains the main settlement currency for China as well. According to the People's Bank of China, only $13.4 \%$ of the total trade turnover of the country with foreign partners in 2019 was settled in yuan. A significant part of the settlements for export-import operations (over 80\%) is carried out in US dollars. In addition, the US dollar has a high protection against inflationary risks and is the main means of settlement between countries. The US dollar is actively used by countries to lend to the real sector of national economies for domestic and international transactions [26].

The interests of Russia and China in the issue of de-dollarization do not converge in many ways. In the medium term, China intends to create a de-dollarized financial and investment space in part of Eurasia with a focus on the Chinese interest in yuan internationalization. Thus, any agreement with Russia on joint actions on de-dollarization would mean an obstacle for China in the investments takeover of the relatively weak financial systems of the Central Asian countries. It is in this region that China will be able to compete with the United States in the financial and economic sphere, provided that Russia's position in this region.

In addition, unlike China, which, although experiencing problems in cooperation with the United States, is still not limited in access to investment resources, Russia must act in extremely difficult financial and investment conditions, considering the applied sanctions limiting its access to the financial resources. Thus, de-dollarization becomes a necessity for Russia.

Starting from 2018, Russia has been actively pursuing a policy of diversifying international reserves. In 2018 the 
share of foreign exchange reserves decreased to $79.35 \%$ and in 2020 amounted to $74.61 \%$. The reason for the decrease in the share of foreign currencies in the structure of the Bank of Russia's international reserves is the diversification of assets in favor of increasing the share of gold. If in 2006 the share of gold was $2.69 \%$, then in 2018 it was $18.55 \%$, and in 2020 it reached $23.29 \%$ of the country's international reserves [27]. In 2006 Russia's foreign exchange reserves were concentrated on four currencies: the US dollar (49\%), the euro $(40 \%)$, the pound sterling (10\%) and the Japanese yen (1\%). In 2010, the Canadian dollar was added to the reserve currency composition, in 2012 - the Australian dollar, in 2015 - the Chinese yuan. The expansion of the number of currencies in Russia's international reserves was accompanied by a change in their share. Thus, for the period from December 31,2017 , to December 31,2020, the share of the dollar in the international reserves of the Bank of Russia decreased more than twice - from $45.8 \%$ to $21.2 \%$. At the same time, the share of the euro increased by almost a third from $21.7 \%$ to $29.2 \%$, and the yuan more than four times, from 2.8 to $12.8 \%$ [28]. The structure of Russian foreign exchange reserves is provided in the Figure 8. In June 2021, the Ministry of Finance and the Central Bank of Russia announced a decision to completely abandon the storage of funds of the National Welfare Fund in dollars. As part of the de-dollarization program, in 2018, Russia began actively selling off American debt securities. Investments in US bonds decreased to $\$ 3.8$ billion as of May 2021 [29].

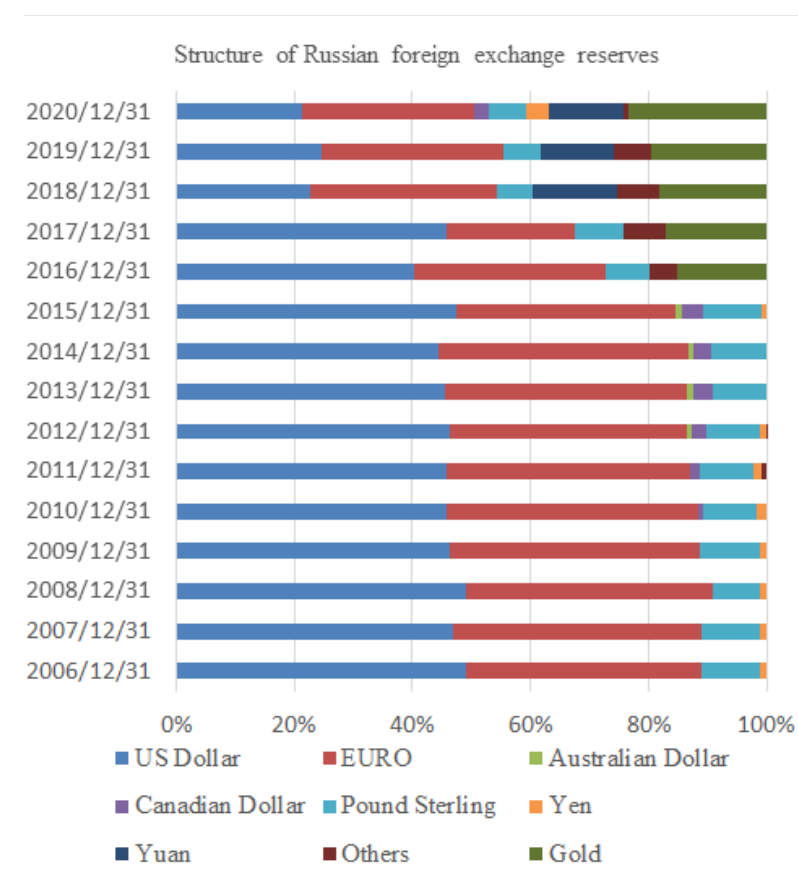

Figure 8. The structure of Russian foreign exchange reserves [30]

Settlements in US dollars for the export of hydrocarbons from Russia have significantly decreased.
So, if in 2013 US dollars accounted for $73 \%$ of payments for hydrocarbon supplies to the EU, $96.2 \%$ to China, then in 2018 , respectively, $54.4 \%$ to the EU, $75.1 \%$ to China; and in $2020,42.3 \%$ to the EU and $22.7 \%$ to China [31].

\section{Conclusions}

Based on this research the following four important conclusions could be made.

First, the level of financial dollarization in the Eurasian Economic Union member states, especially in Belarus and Armenia remain significant due to inefficient monetary policy, macroeconomic volatility, and devaluation of national currencies. Meanwhile the lower level of dollarization in Kyrgyzstan, Kazakhstan and Russia may change toward the higher level since there is not full confidence in the national currencies. However, Russia, placed under strict sanctions, will be forced to reduce its dependence on external factors for the development of the domestic economy, while at the same time leading its partners in the EAEU in this direction.

Second, de-dollarization is not just getting rid of the dollar's dominance in international and regional settlements. De-dollarization is the process of withdrawing economies from the American-centered monetary and financial system. The key direction of development may be sectoral de-dollarization, the formation of sectoral economic spaces in which the dollar will not be the only unit of account. In this context, the factor of de-dollarization could be the refusal to use the US dollar in payments for oil, which becomes quite real in the conditions of increasing Chinese pressure on Saudi Arabia, the main support of the United States in OPEC. China is seeking to replace the dollar with the yuan as payment for the supply of oil and petroleum products to the country. The transition to the "oil yuan" will allow the Chinese currency to be brought to a higher level in the system of international finance and will negatively affect the position of the US dollar. In addition, other major importers of oil and petroleum products may follow the example of China.

Third, in the context of the aggravation of US-Chinese trade and economic relations, the task of de-dollarization becomes not so much economic as political, given the countries' aspirations to negotiate among themselves bypassing the United States. Such an independent policy of countries from the United States cannot but go unnoticed by the American establishment. It is unlikely that the United States will accept such a situation. On the contrary, we can expect the United States, represented by the Federal Reserve, to search for the weakest links for increasing the expansion of the dollar and pursuing a policy of dollarization of the world economy.

Finaly, one should not ignore the fact that the positions of the US dollar in international payments are more 
significant than other currencies. The share of the US dollar in global SWIFT payments in June 2021 was $40.64 \%$, the euro $37.92 \%$ [32]. The share of the yuan did not exceed $2.5 \%$. In $2019,44 \%$ of all transactions on the global Forex market were conducted with the participation of the US dollar, $16 \%$ - with the participation of the euro and only $2 \%$ - with the participation of the Chinese yuan [33]. Thus, given the above data, it is hardly worth arguing about the weakening of the US dollar's position. In addition, all dollar transactions, including transactions between non-US companies, pass through the Fedwire system, which is located in the US jurisdiction and under the control of the Federal Reserve.

\section{REFERENCES}

[1] Ozsoz, Emre "Evaluating the Effects of Deposit Dollarization in Financial Intermediation in Transition Economies", Eastern European Economics, 2009, Vol. 47, No. 4, pp. 5-24. DOI 10.2753/EEE0012-8775470401

[2] Salama, Pierre "La dollarisation - Essai sur la monnaie, l'industrialisation et l'endettement des pays sous-développés" - Paris: Agalma, La Découverte, 1989.

[3] Savastano, Miguel A. "Dollarization in Latin America: Recent Evidence and Some Policy Issues", International Monetary Fund Working Papers, 1996, No. 4 (WP/96/04). Washington, D.C.: International Monetary Fund. Available at: https://www.elibrary.imf.org/view/journals/001/1996/00 4/001.1996.issue-004-en.xml

[4] Garcia-Escribano, Mercedes, Sosa Sebastian "What is Driving Financial De-dollarization in Latin America?", International Monetary Fund Working Papers, 2011, No. 10 (WP/11/10). - Washington, D.C.: International Monetary Fund. Available at: https://www.imf.org/external/pubs/ft/wp /2011/wp1110.pdf

[5] Goujon, Michaël "Fighting Inflation in a Dollarized Economy: The Case of Vietnam", Journal of Comparative Economics, 2006, Vol. 34, No. 3, pp. 564-581. DOI: 10.1016/j.jce.2006.06.001

[6] Basso, Henrique S.; Calvo-Gonzalez, Oscar; Jurgilas Marius. "Financial Dollarization: The Role of Banks and Interest Rates", European Central Bank Working Papers, 2007, No. 748. Available at: https://www.ecb.europa.eu/pub/pdf/scpw ps/ecbwp748.pdf

[7] Honohan, Patrick "Deposit Dollarization: What's Happening, What Can Be Done", World Bank, PREM Notes, 2004, No. 92. Available at: https://openknowledge.worldbank.org/han dle/10986/11257

[8] Chuvakhina Larisa G., "Политика ФРС США по долларизации мировой экономики” \{The US FRS policy on dedollarization of the world economy $\}$, Gorizonty ekonomiky, 2019, No.1 (47), pp. 74-79. Available at: https://www.elibrary.ru/item.asp?id=37106648

[9] Arteta, Carlos Oscar, Are Financially Dollarized Countries More Prone to Costly Crises? (March 2003). Available at
SSRN: $\quad$ https://ssrn.com/abstract $=392661$

or http://dx.doi.org/10.2139/ssrn.392661.

[10] Gavranić Kristijan, Miletić Dejan. "US dollar stability and global currency reserves." Eurasian Journal of Economics and Finance, 4(3), 2016, 14-24. P. 23. https:/eurasianpublications.com/eurasian-journal-of-econo mics-and-finance/current-past-issues/vol-4-no-3/ DOI:10.1 5604/ejef.2016.04.03.002.

[11] Feige, Edgar L.; Dean. James "Dollarization and Euroization in Transition Countries: Currency Substitution, Asset Substitution, Network Externalities and Irreversibility", in V. Alexander, J. Melitz and G.M. von Furstenberg (eds.), Monetary Unions and Hard Pegs: Effects on Trade, Financial Development, and Stability, - New York and Oxford: Oxford University Press, 2004, pp. 303-319. Available at:https://www.researchgate.net/profile/Edgar-Fei ge/publication/23745320_Dollarization_and_Euroization_in _Transition_Countries_Currency_Substitution_Asset_Substi tution_Network_Externalities_and_Irreversibility/links/091 2f505 $\overline{7} 2 \mathrm{c} 33345 \overline{6} 3000000 /$ Dollarization-and-Euroization-inTransition-Countries-Currency-Substitution-Asset-Substituti on-Network-Externalities-and-Irreversibility.pdf

[12] Tumarova T.G., Kornilovich S.G. "Процессы замещения валют и активов в странах Евразийского Экономического Сообщества" \{The process of substitution of currencies and assets in the member countries of Eurasian Economic Union\}, Vestnik Sankt-Peterburgskogo universiteta, S.8: Management, 2007, No. 2, pp. 134-156. Available at: https://www.elibrary.ru/item.asp?id=9496839

[13] Levy-Yeyati Eduardo, 2021. "Financial dollarization and de-dollarization in the new millennium," Department of Economics Working Papers wp_gob_2021_02, Universidad Torcuato Di Tella. Available at: https://ideas.repec.org/p/udt/wpecon/wp_gob_2021_02.html

[14] Platonova I.N. "De-dollarization as a Manifestation of the Transition of International Monetary Relations to Polycentrism", Proceedings of the External Challenges and Risks for Russia in the Context of the World Community's Transition to Polycentrism: Economics, Finance and Business (ICEFB 2019), Atlantis Press, 2019. DOI https://doi.org/10.2991/icefb-19.2019.18

[15] Dabrowski Marek "Can the Euro Dethrone the US Dollar as the Dominant Global Currency? Not so Soon, if Ever.", Monetary Dialogue Papers, June 2020, European Parliament. P.31, June 2020. ISBN 978-92-846-6701-7. Available at: https://www.europarl.europa.eu/cmsdata/2075 04/CASE_FINAL\%20online.pdf

[16]Faudot Adrien, Ponsot Jean-François. "The Dollar Dominance: Recent Episode of Trade Invoicing and Debt Issuance." Journal of Economic Integration. Vol.31 No.1, March 2016, 41 64. P.48. DOI: https://doi.org/10.11130/jei. 2016.31.1.41

[17] Siddiqui Kalim. "The U.S. Dollar and the World Economy: A Critical Review." Athens Journal of Business \& Economics Volume 6, Issue 1 - Pages 21-44.P.21 2020 DOI: https://doi.org/10.30958/ajbe.6-1-2

[18] Kamin, Steven B. \& Ericsson, Neil R., 2003. "Dollarization in post-hyperinflationary Argentina," Journal of International Money and Finance, Elsevier, vol. 22(2), pages 185-211, April. 
[19] Eurasian Economic Commission, 2021. Data retrieved on 27.07.2021 from: http://www.eurasiancommission.org/ru/ac t/integr_i_makroec/dep_stat/fin_stat/time_series/Pages/mon etary.aspx

[20]Eurasian Economic Commission, 2021. Data retrieved on 27.07.2021 from: http://www.eurasiancommission.org/ru/ac t/integr_i_makroec/dep_stat/fin_stat/time_series/Pages/mon etary.aspx

[21] Eurasian Economic Commission, 2021. Data retrieved on 27.07.2021 from: http://www.eurasiancommission.org/ru/ac t/integr_i_makroec/dep_stat/fin_stat/time_series/Pages/mon etary.aspx

[22] Eurasian Economic Commission, 2021. Data retrieved on 27.07.2021 from: http://www.eurasiancommission.org/ru/ac t/integr_i_makroec/dep_stat/fin_stat/time_series/Pages/mon etary.asp $\mathrm{x}$

[23]Eurasian Economic Commission, 2021. Data retrieved on 27.07.2021 from: http://www.eurasiancommission.org/ru/ac t/integr_i_makroec/dep_stat/fin_stat/time_series/Pages/mon etary.aspx

[24] Eurasian Economic Commission, 2021. Data retrieved on 27.07.2021 from: http://www.eurasiancommission.org/ru/ac t/integr_i_makroec/dep_stat/fin_stat/time_series/Pages/mon etary.aspx

[25] Workman Daniel, World's Top Exports. 2021. Data retrieved on 27/03/2021 from: https://www.worldstopexports.com/cru de-oil-imports-by-country/

[26] BIS, Global liquidity indicators. Data retrieved on 14.01.2021 from: https://www.bis.org/statistics/gli.htm?m= 6\%7C333\%7C690

[27] Central Bank of Russia. Data retrieved on 26.04.2021 from: https://cbr.ru/hd_base/mrrf/mrrf_m/?UniDbQuery.Posted=T rue $\&$ UniDbQuery.From $=01.2000 \&$ UniDbQuery.To $=04$

[28] Global Finances. Data retrieved on 27.07.2021 from: http://global-finances.ru/zolotovalyutnyie-rezervyi-rossii/

[29] Statista.com. Data retrieved on 27.07.2021 from: https://www.statista.com/statistics/1226054/value-of-unitedstates-treasury-securities-held-by-russia/

[30] Central Bank of Russia. Overviews of the Bank of Russia's activities in managing reserve currency assets 2007-2020. Available at: https://cbr.ru/

[31] Central Bank of Russia. Statistics. Retrieved on 26/04/2021 from: http://www.cbr.ru/vfs/statistics/credit_statistics/cur_st r.xlsx

[32] SWIFT: Global payments by currency. Retrieved from: https://www.swift.com/our-solutions/compliance-and-share $\mathrm{d}$-services/business-intelligence/renminbi/rmb-tracker/rmb-t racker-document-centre? category $\% 5 \mathrm{~B} 0 \% 5 \mathrm{D}=168936 \&$ page $=0$

[33] Turnover of OTC foreign exchange instruments, by currency Retrieved from: https://stats.bis.org/statx/srs/table/d11. 